\title{
Design, Synthesis, and Antitumor Activity of Olmutinib Derivatives Containing Acrylamide Moiety
}

\author{
Xiaohan Hu, Sheng Tang, Feiyi Yang, Pengwu Zheng, Shan Xu ${ }^{\dagger}$, Qingshan Pan * and Wufu Zhu * \\ School of Pharmacy, Jiangxi Science \& Technology Normal University, Nanchang 330013, China; \\ huxiaohan1717@163.com (X.H.); shengtang_1219@163.com (S.T.); 18380539689@163.com (F.Y.); \\ Zhengpw@126.com (P.Z.); Shanxu9891@126.com (S.X.) \\ * Correspondence: qingshan_pan@hnu.edu.cn (Q.P.); zhuwufu-1122@163.com or zhuwf@jxstnu.edu.cn (W.Z.) \\ + Tel.: +86-791-8380-2393 (S.X.).
}

Citation: Hu, X.; Tang, S.; Yang, F.; Zheng, P.; Xu, S.; Pan, Q.; Zhu, W. Design, Synthesis, and Antitumor Activity of Olmutinib Derivatives Containing Acrylamide Moiety. Molecules 2021, 26, 3041. https:// doi.org/10.3390/molecules26103041

Academic Editors: Loredana Salerno and Sebastiano Intagliata

Received: 25 March 2021

Accepted: 12 May 2021

Published: 20 May 2021

Publisher's Note: MDPI stays neutral with regard to jurisdictional claims in published maps and institutional affiliations.

Copyright: (c) 2021 by the authors. Licensee MDPI, Basel, Switzerland. This article is an open access article distributed under the terms and conditions of the Creative Commons Attribution (CC BY) license (https:// creativecommons.org/licenses/by/ $4.0 /)$.

\begin{abstract}
Two series of olmutinib derivatives containing an acrylamide moiety were designed and synthesized, and their IC $_{50}$ values against cancer cell lines (A549, H1975, NCI-H460, LO2, and MCF-7) were evaluated. Most of the compounds exhibited moderate cytotoxic activity against the five cancer cell lines. The most promising compound, H10, showed not only excellent activity against EGFR kinase but also positive biological activity against PI3K kinase. The structure-activity relationship (SAR) suggested that the introduction of dimethylamine scaffolds with smaller spatial structures was more favorable for antitumor activity. Additionally, the substitution of different acrylamide side chains had different effects on the activity of compounds. Generally, compounds H7 and H10 were confirmed as promising antitumor agents.
\end{abstract}

Keywords: acrylamide; olmutinib derivatives; EGFR; inhibitor

\section{Introduction}

Recent studies have shown that the mutation rate and overexpression rate of epidermal growth factor receptor (EGFR; a transmembrane protein) of patients with non-small-cell lung cancer (NSCLC) are as high as 75\% in vivo [1,2]. EGFR is associated with various growth processes of cancer, including proliferation, differentiation, migration, apoptosis, and angiogenesis [3]. Therefore, EGFR has garnered considerable attention as an antitumor drug target, giving rise to numerous investigations of EGFR kinase inhibitors to disrupt and inhibit the proliferation and growth of tumor cells [4]. The first-generation EGFR inhibitor gefitinib (1) (Figure 1) and the second-generation EGFR inhibitor afatinib (2) have good inhibitory effects on the EGFR ${ }^{\mathrm{L} 858 \mathrm{R}}$ mutation and the EGFR ${ }^{\mathrm{T} 790 \mathrm{M}}$ mutation, respectively [5-7]. However, the first- and second-generation inhibitors have poor kinase selectivity between the EGFR ${ }^{\mathrm{T} 790 \mathrm{M}}$ mutant and the wild type. Moreover, their clinical efficacy is limited. The third-generation EGFR inhibitor olmutinib [8,9] (3) was developed by Hanmei Pharmaceutical Company, and is an irreversible inhibitor for the treatment of patients with locally advanced or EGFR ${ }^{\mathrm{T} 790 \mathrm{M}}$-mutant NSCLC (Figure 2) [10]. The IC 50 values of 3 against HCC827 (EGFR $\left.{ }^{\text {dell19}}\right)$, H1975 (EGFR ${ }^{\text {L858R/T790M }}$ ), and A549 (EGFR ${ }^{\text {WT }}$ ) cells were $9.2 \mathrm{nM}, 10 \mathrm{nM}$, and $225 \mathrm{nM}$, respectively. This indicated that 3 had strong selectivity for the EGFR mutation. However, 3 had toxic side effects such as palmoplantar keratoderma and diarrhea. Therefore, the goal of this study to obtain new olmutinib derivatives which can overcome the side effects of skeleton migration.

To guide our modification, a molecular docking simulation of $\mathbf{3}$ and EGFR protein was performed. The thienopyrimidine structure of $\mathbf{3}$ was inserted into the larger hydrophobic band of the protein and could form hydrogen bonds with MET-793 in the hinged region, as shown in Figure 2A,B. Therefore, we transformed the thiophene pyrimidine structure into thiophene and pyrimidine to explore the antiproliferative activity of the target compounds when fully occupying the protein cavity. At the same time, inspired by WZ4002 
(4), we replaced the phenylpiperazine structure of $\mathbf{3}$ with an anisidine side chain and an electron-withdrawing cyano group [11]. Different acrylamide moieties were used to explore the influence of side-chain length and halogen atoms on the activities of compounds. We used this design idea to synthesize the first series of target compounds (Figure 3).<smiles>COc1cc2ncnc(Nc3ccc(F)c(Cl)c3)c2cc1OCCCN1CCOCC1</smiles>

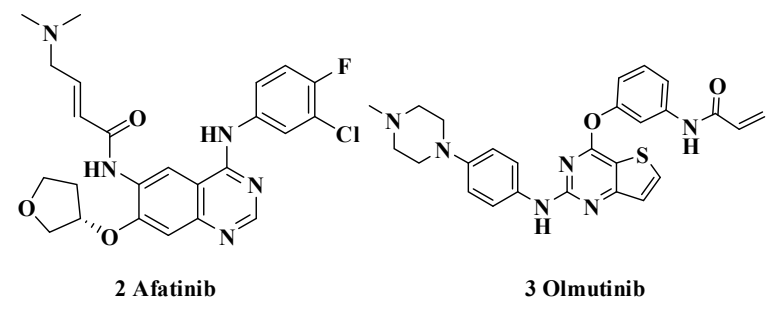<smiles>C=CC(=O)Nc1cccc(OC2=C(Cl)C=NC3=Nc4ccc(N5CCC(C)CC5)cc4N2C3)c1</smiles>

4 WZ4002<smiles>FC(F)c1nc(-c2cncc3ccccc23)cc(C2CCOCC2)n1</smiles>

5 ZSTK474<smiles></smiles>

6 GDC-0941

Figure 1. Structures of the representative EGFR and PI3K inhibitors.

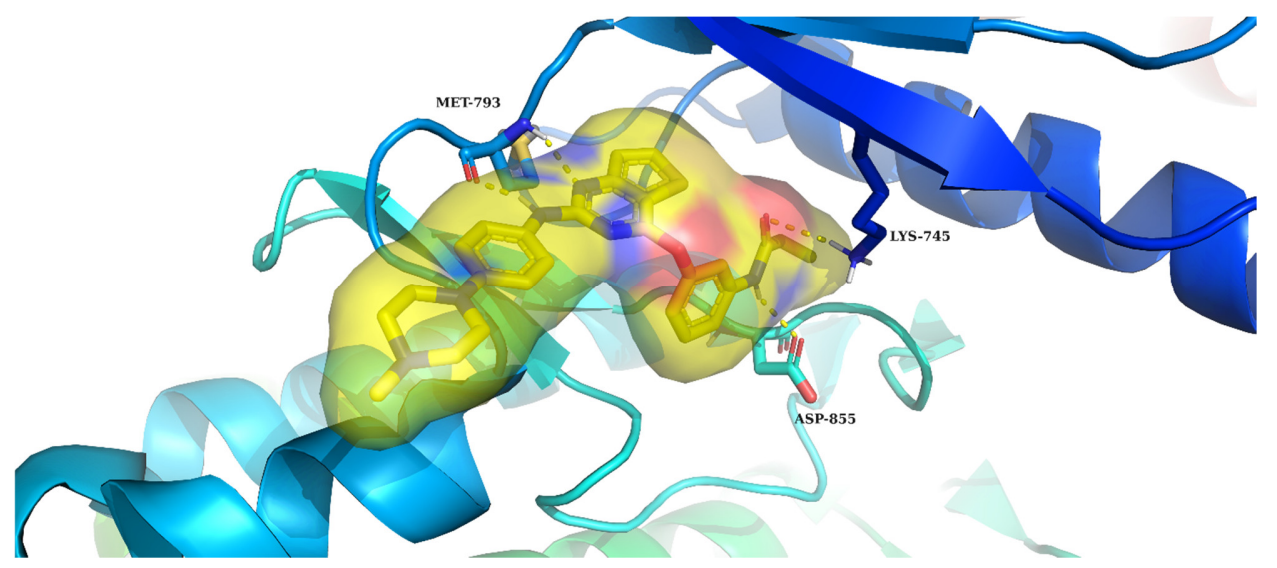

(A)

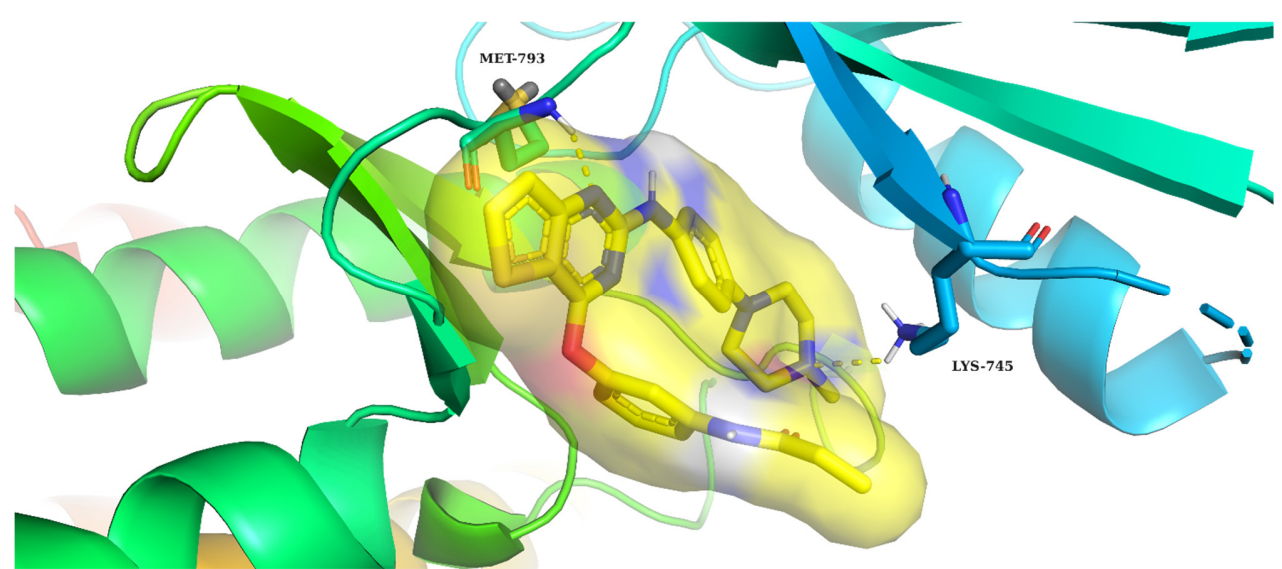

(B)

Figure 2. Olmutinib docking model: (A) olmutinib-EGFR ${ }^{\mathrm{T} 790 \mathrm{M}}$ (PDB code: $\left.3 \mathrm{ika}\right)$; (B) olmutinibEGFR $^{\text {WT }}$ (PDB code: 4zau). 


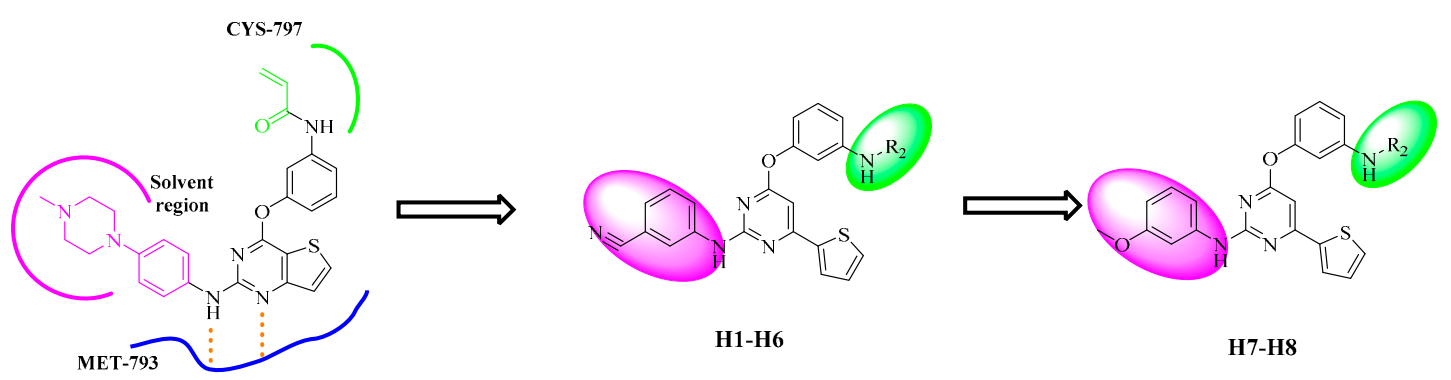

Figure 3. Design strategies for the first series of compounds.

To design of the second series of target compounds (Figure 4), we retained the thiophene and pyrimidine core and introduced the triazine structure of phosphatidylinositol3-kinase (PI3K) inhibitor ZSTK474 (5) while at the same time, the structures of thiophene and pyrimidine were transformed into triazine and pyrimidine $[12,13]$. The introduction of the 1,3,5-triazine ring increased the polarity of the molecule to better form key hydrogen bonds with MET-793 [14]. The oxygen of the morpholine ring of GDC-0941 (6) can form hydrogen bonds with the VAL-851 of the PI3K hinge region. Moreover, the introduction of the morpholine ring enhanced the mTOR-inhibitory activity of the compound; thus, the morpholine ring group was preserved [15-17]. Michael receptors were introduced in the solvent region to explore the interaction with the surrounding amino acids. Based on this design strategy, we completed the synthesis of the second series of compounds. We expected to obtain an ideal inhibitor with a better EGFR-inhibitory activity and to explore whether the target compound has an inhibitory effect on PI3K following the modifications described above.

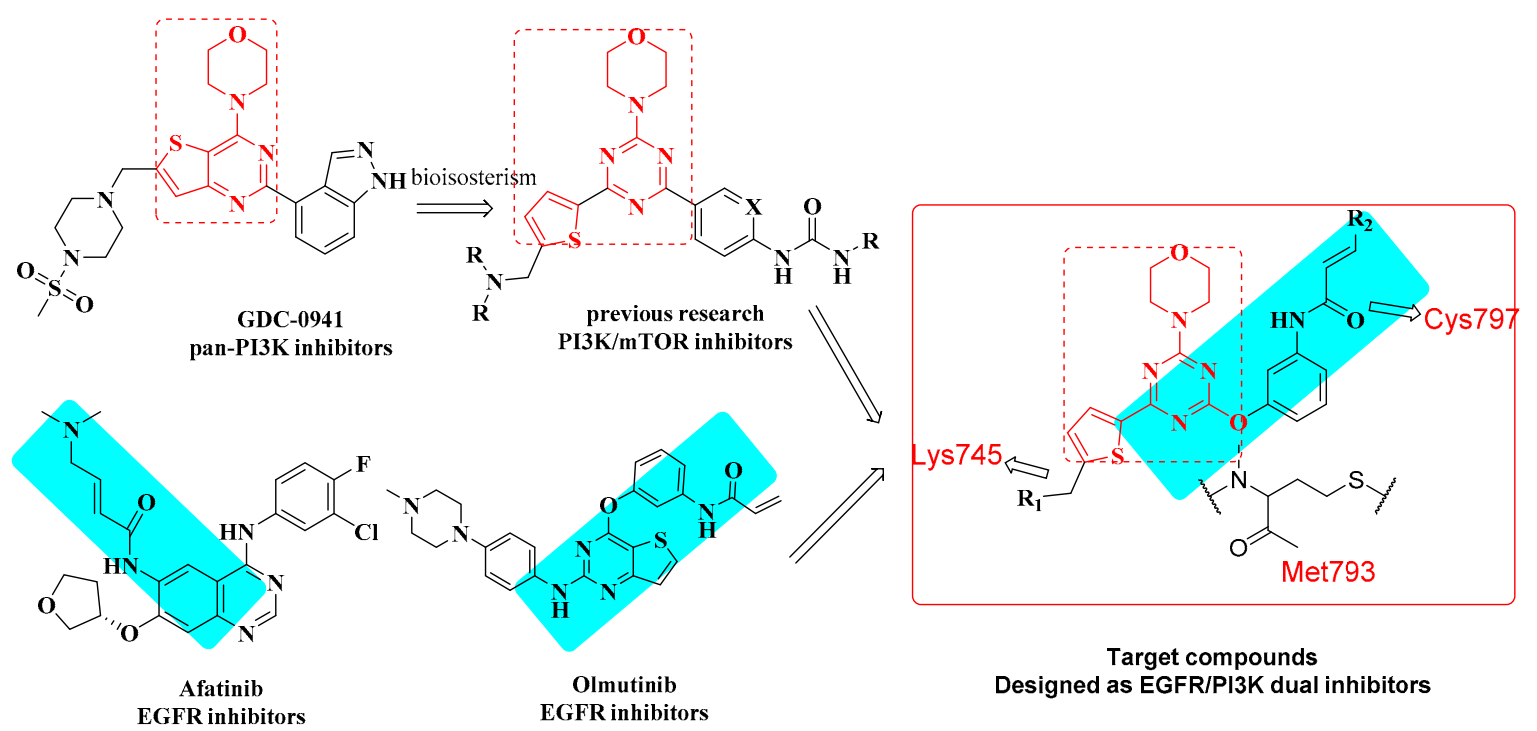

Figure 4. Design strategies for the second series of compounds.

\section{Results and Discussion}

\subsection{Chemistry}

According to the structure-based drug design (SBDD) strategy, we designed and synthesized two series of olmutinib derivatives as EGFR inhibitors containing an acrylamide moiety. The synthetic routes of target compounds H1-H16 are outlined in Schemes 1 and 2. 


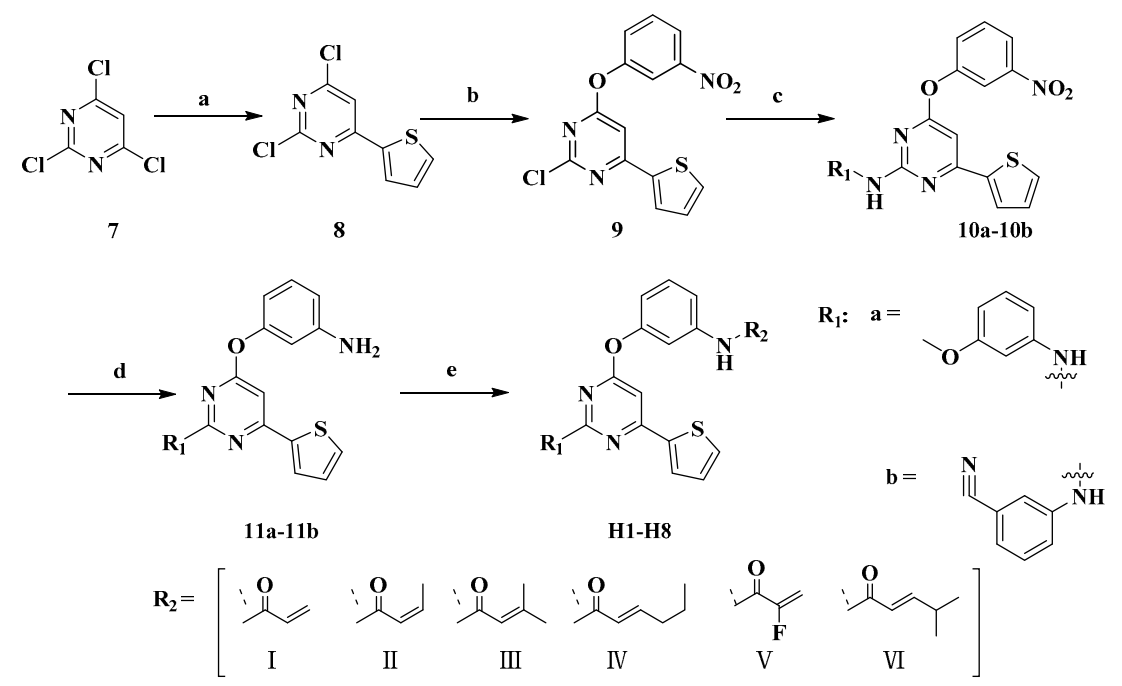

Scheme 1. The synthetic route for target compounds H1-H8. Reagents and conditions: (a) 1,2dimethoxyethane, thiophen-2-yl-boronic acid, $90{ }^{\circ} \mathrm{C}, 1.5 \mathrm{~h}$; (b) 1,4-dioxane, metanitrophenol, r.t., $4 \mathrm{~h}$; (c) acetonitrile, toluene-p-sulfonic acid, amines, $100^{\circ} \mathrm{C}, 4-5 \mathrm{~h}$; (d) ethanol, ferric chloride, water and hydrazine, active carbon, $80^{\circ} \mathrm{C}, 4 \mathrm{~h}$; (e) dichloromethane, acid amides, bicarbonate, $0{ }^{\circ} \mathrm{C}, 1-2 \mathrm{~h}$.

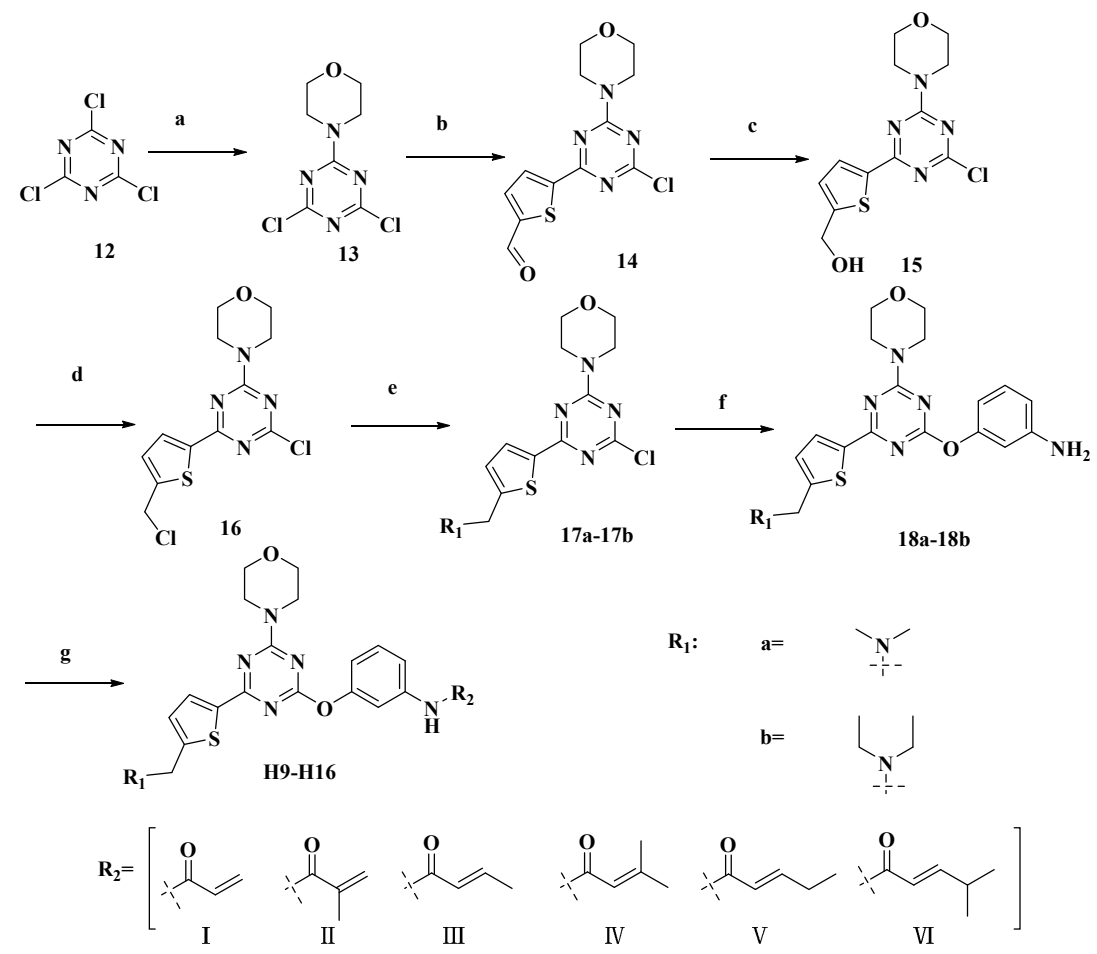

Scheme 2. The synthetic route for target compounds H9-H16. Reagents and conditions: (a) acetone, morpholine, $0{ }^{\circ} \mathrm{C}, 1 \mathrm{~h}$; (b) 1,2-dimethoxyethane, 5-aldyl-2-thiophene boric acid, $\mathrm{K}_{2} \mathrm{CO}_{3}, 75^{\circ} \mathrm{C}, 24 \mathrm{~h}$; (c) methanol, $\mathrm{NaBH}_{4}, 0^{\circ} \mathrm{C}, 0.5 \mathrm{~h}$; (d) DCM, $\mathrm{SOCl}_{2}, \mathrm{~N}, \mathrm{~N}$-dimethylformamide, r.t., 2 h; (e) isopropanol, $\mathrm{N}$,N-diisopropylethylamine, amines, $75{ }^{\circ} \mathrm{C}, 1 \mathrm{~h}$; (f) THF, tert-butoxide, 3-aminophenol, $0{ }^{\circ} \mathrm{C}, 1 \mathrm{~h}$; (g) dichloromethane, acid amides, bicarbonate, $0{ }^{\circ} \mathrm{C}, 1-2 \mathrm{~h}$.

As shown in Scheme 1, we used commercially available 2,4,6-trichloropyrimidine (7) and thiophen-2-ylboronic acid to obtain 11a-11b through cyclization, chlorination, and nucleophilic substitution reactions. Compounds 11a-11b reacted with different amide side chains to give the target compounds H1-H8. As shown in Scheme 2, we used 1,3,5triazine as the starting material to obtain $\mathbf{1 8 a - 1 8 b}$ with different amines via six steps of 
substitution, reduction, and chlorination. Finally, 18a-18b reacted with different amide side chains to give the target compounds H9-H16. The structural information of target compounds was confirmed by ${ }^{1} \mathrm{H}-\mathrm{NMR},{ }^{13} \mathrm{C}-\mathrm{NMR}$, and TOF MS (ES+), the results of which were consistent with the structures depicted.

\subsection{Biological Discussion}

Four human tumor cell lines (A549, H1975, NCI-H460, and MCF-7) and human normal cell line LO2 were selected to evaluate the antiproliferative activity of all target compounds in vitro. Olmutinib was used as a positive control. Results are summarized in Table 1, where the values are the average of at least three independent experiments. Compared with the lead compound olmutinib, most target compounds were less toxic to the normal cell line LO2, which indicates that the target compounds had a selective inhibitory effect on cancer cells. After the introduction of electron-withdrawing cyanide, the antiproliferative activities of compounds $\mathbf{H 1}-\mathbf{H} \mathbf{6}$ that were substituted with cyano groups showed moderate inhibitory activity against all the cell lines. However, the antiproliferative activities of the compounds that were substituted with the anisidine side chain performed better than the cyano group chain. This indicates that the introduction of the electron-withdrawing units could not increase the antiproliferative activity of the compounds. Obviously, compound H7 showed the greatest inhibitory activities against A549 and H1975 cancer cell lines, with $\mathrm{IC}_{50}$ values of $4.37 \pm 0.50 \mu \mathrm{M}$ and $4.59 \pm 0.46 \mu \mathrm{M}$, respectively, which were similar to the reference compound of olmutinib.

Table 1 shows that the introduction of the 1,3,5-triazine ring and morpholine ring significantly enhanced the antiproliferation activity of the compounds. At the same time, we found that the antiproliferative activities of the compounds that were substituted with dimethylamine groups, were better than those that were substituted with diethylamine groups. Therefore, we speculate that the inner cavity area of the hydrophobic region is limited and only can accommodate molecules with smaller structures. From the docking results (Figure 5B), it was found that the dimethylamine group of compound $\mathbf{H 1 0}$ penetrated into the interior of the protein (4zau) and completely occupied the space, which suggests that the introduction of a larger group than dimethylamine will not increase the activity of these compounds. The optimal compound $\mathbf{H 1 0}$ showed excellent antiproliferative activity against $\mathrm{A} 549$ and MCF-7 cancer cell lines, with $\mathrm{IC}_{50}$ values of $3.36 \pm 1.59 \mu \mathrm{M}$ and $13.05 \pm 1.36 \mu \mathrm{M}$, respectively, which were superior to the drug of reference. The selectivity of compound $\mathbf{H 1 0}$ to A549 cells was 29.76 times than to $\mathrm{LO} 2$ cells, and about 5 times that of the lead compound olmutinib.

Table 1. Structures and cytotoxicity of compounds H1-H16.
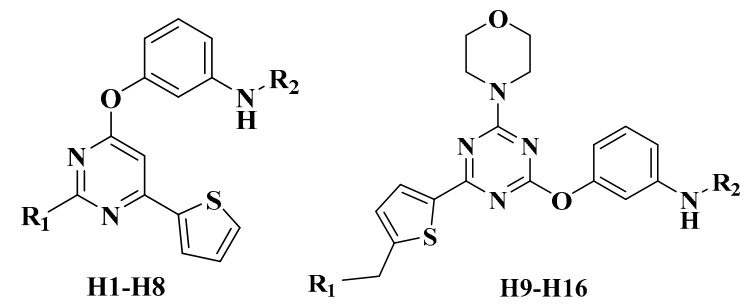

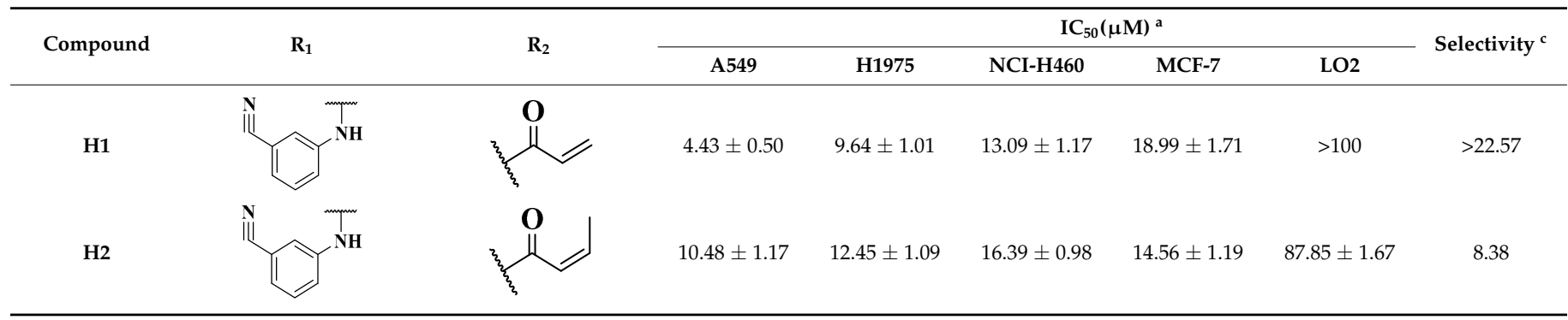


Table 1. Cont.

\begin{tabular}{|c|c|c|c|c|c|c|c|c|}
\hline \multirow{2}{*}{ Compound } & \multirow{2}{*}{$\mathrm{R}_{1}$} & \multirow{2}{*}{$\mathbf{R}_{2}$} & \multicolumn{5}{|c|}{$\mathrm{IC}_{50}(\mu \mathrm{M})^{\mathrm{a}}$} & \multirow{2}{*}{ Selectivity $^{c}$} \\
\hline & & & A549 & H1975 & NCI-H460 & MCF-7 & LO2 & \\
\hline H3 & & & $27.69 \pm 1.24$ & $21.85 \pm 1.33$ & $25.79 \pm 1.38$ & $35.83 \pm 1.64$ & $>100$ & $>3.61$ \\
\hline $\mathrm{H} 4$ & & & $37.10 \pm 1.19$ & $25.11 \pm 1.30$ & $23.38 \pm 1.49$ & $27.04 \pm 1.63$ & $>100$ & $>2.70$ \\
\hline H5 & & & $>100$ & $>100$ & $>100$ & $>100$ & $>100$ & - \\
\hline H6 & & & $15.56 \pm 0.81$ & $11.94 \pm 1.11$ & $18.09 \pm 0.71$ & $17.73 \pm 1.01$ & $>100$ & $>6.43$ \\
\hline H7 & & & $4.37 \pm 0.50$ & $4.59 \pm 0.46$ & $13.48 \pm 0.52$ & $19.21 \pm 1.12$ & $>100$ & $>22.88$ \\
\hline H8 & & & $19.01 \pm 1.34$ & $21.52 \pm 1.21$ & $24.12 \pm 1.28$ & $49.13 \pm 2.13$ & $>100$ & $>5.26$ \\
\hline H9 & & & $23.46 \pm 1.43$ & $12.82 \pm 1.25$ & $28.24 \pm 1.78$ & $53.86 \pm 1.73$ & $>100$ & $>4.26$ \\
\hline H10 & & & $3.36 \pm 1.59$ & $1.16 \pm 1.53$ & $10.65 \pm 2.02$ & $13.05 \pm 1.36$ & $>100$ & $>29.76$ \\
\hline H11 & & & $13.54 \pm 1.13$ & $5.57 \pm 1.53$ & $19.72 \pm 1.16$ & $25.83 \pm 1.31$ & $>100$ & $>7.39$ \\
\hline H12 & & & $21.86 \pm 1.54$ & $13.55 \pm 1.94$ & $23.81 \pm 2.05$ & $64.01 \pm 1.80$ & $>100$ & $>4.57$ \\
\hline H13 & & & $23.45 \pm 1.89$ & $21.52 \pm 1.21$ & $54.53 \pm 2.86$ & $32.45 \pm 1.73$ & $>100$ & $>4.26$ \\
\hline H14 & & & $20.56 \pm 2.30$ & $17.78 \pm 1.34$ & $46.22 \pm 1.43$ & $41.61 \pm 1.61$ & $>100$ & $>4.86$ \\
\hline H15 & & & $21.35 \pm 1.58$ & $19.46 \pm 1.55$ & $62.43 \pm 2.94$ & $38.54 \pm 1.78$ & $>100$ & $>4.68$ \\
\hline H16 & & & $36.14 \pm 1.61$ & $15.57 \pm 2.55$ & $30.28 \pm 1.68$ & $51.82 \pm 1.27$ & $>100$ & $>2.77$ \\
\hline Olmutinib $^{b}$ & - & - & $4.29 \pm 0.21$ & $0.52 \pm 0.10$ & $5.29 \pm 0.59$ & $26.90 \pm 0.93$ & $25.76 \pm 1.31$ & 6.00 \\
\hline
\end{tabular}

${ }^{a}$ The values are an average of three separate determinations; ${ }^{b}$ used as a positive control; ${ }^{c} \mathrm{IC}_{50}(\mathrm{LO} 2) / \mathrm{IC}_{50}(\mathrm{~A} 549)$. 


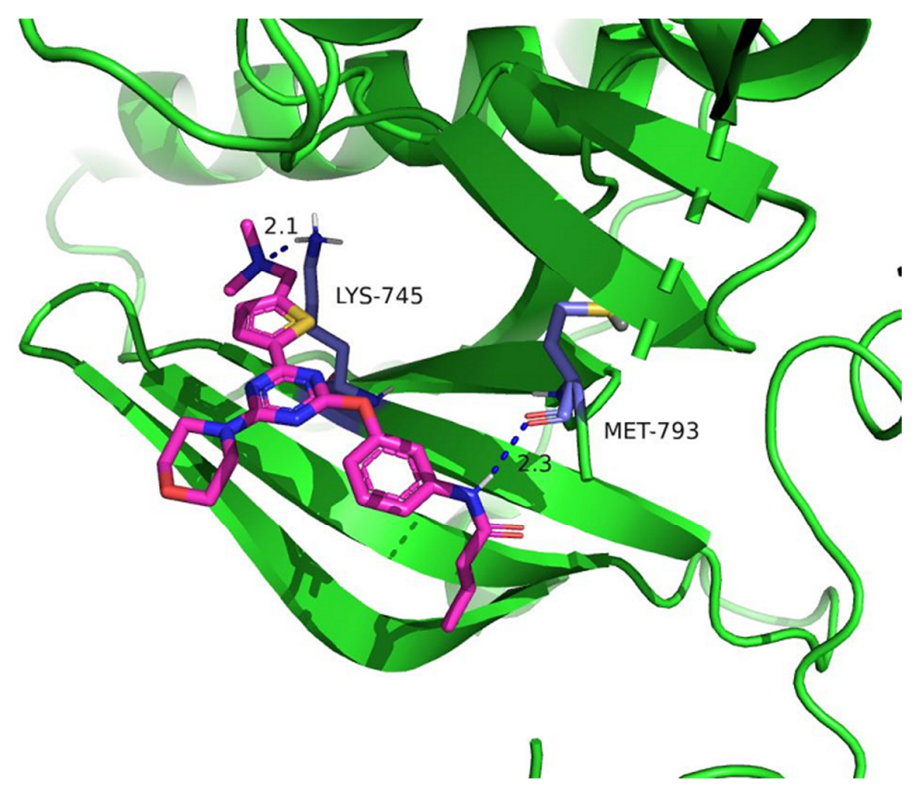

(A)

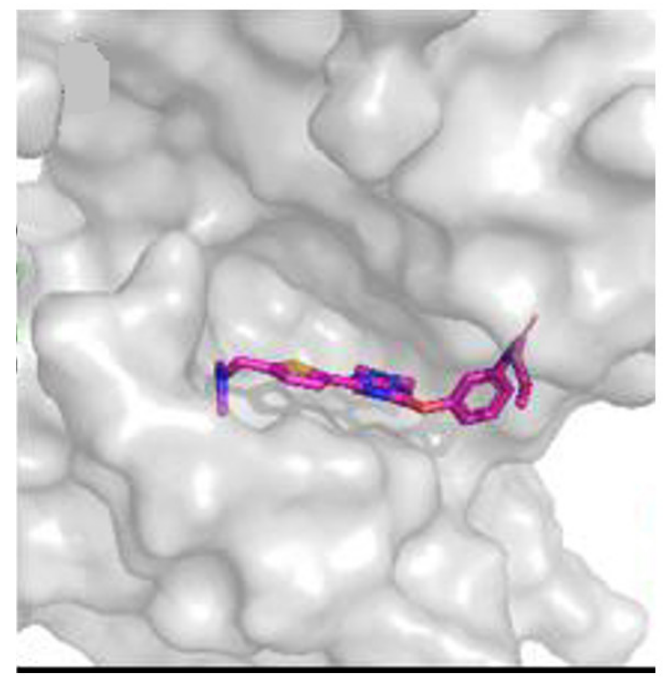

(B)

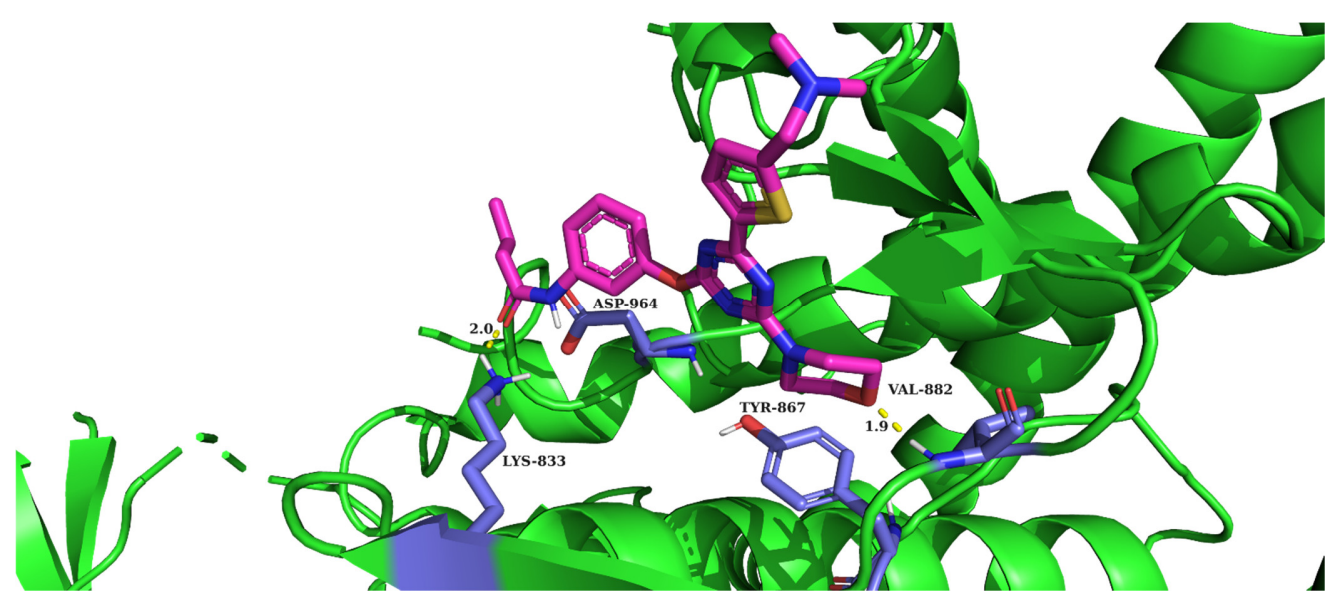

(C)

Figure 5. (A) The binding mode of compound $\mathrm{H10}$ with $\mathrm{EGFR}^{\mathrm{T} 790 \mathrm{M}}$ (3ika) kinase; (B) H10 and protein cavity binding pattern; (C) The binding mode of compound $\mathbf{H 1 0}$ with PI3K $\gamma$ (3L08) kinase. 
Compounds H7 and H10 had excellent antiproliferative activity and were further screened out for kinase inhibition testing. We evaluated compounds $\mathbf{H 7}$ and $\mathbf{H 1 0}$ with EGFR $^{\mathrm{T790M} / \mathrm{L} 858 \mathrm{R}}$ kinases and PI3K $\alpha$ kinases. As shown in Table 2, compounds H7 and H10 exhibited potent inhibition against EGFR ${ }^{\mathrm{T} 790 \mathrm{M} / \mathrm{L} 858 \mathrm{R}}$ kinase. In particular, compound $\mathbf{H 1 0}$ showed better inhibitory activity against PI3K $\alpha$ kinase than the control drug olmutinib. These data demonstrate that compound $\mathbf{H 1 0}$ is expected to be a dual inhibitor of EGFR and PI3K.

\subsection{Molecular Docking Study}

To explore the binding mode of the target compound (H10) with the active site of EGFR, molecular docking simulation was carried out using AutoDock 4.2 software. The docking tutorials and detailed explanations of the AutoDock basic methods we used can be found at the following address: http://autodock.scripps.edu/faqshelp/tutorial (accessed on 25 March 2021). According to the analysis results of the cells and kinases, we chose compound $\mathrm{H10}$ as the example ligand; the structures of EGFR ${ }^{\mathrm{WT}}$ (PDB CODE: 4zau) and EGFR $^{\mathrm{T} 790 \mathrm{M}}$ (PDB CODE: 3ika) were selected as docking models.

Table 2. Enzymatic activities of selected compounds $\mathbf{H 7}$ and $\mathbf{H 1 0}$ against EGFR ${ }^{\mathrm{T} 790 \mathrm{M} / \mathrm{L} 858 \mathrm{R}}$ and $\mathrm{PI} 3 \mathrm{~K} \alpha\left(\mathrm{IC}_{50}, \mu \mathrm{M}\right)$.

\begin{tabular}{ccc}
\hline \multirow{2}{*}{ Compound } & \multicolumn{2}{c}{ IC $_{50}(\mu \mathrm{M})^{\mathbf{a}}$} \\
\cline { 2 - 3 } & EGFR $^{\text {T790M/L858R }}$ & PI3K $\alpha$ \\
\hline H7 & 0.63 & $>10$ \\
H10 & 0.25 & 8.56 \\
Olmutinib b $^{\text {blmul }}$ & 0.01 & $>10$ \\
\hline
\end{tabular}

a The values are an average of three separate determinations; ${ }^{b}$ used as a positive control.

The combination of compound $\mathrm{H} 10$ with the EGFR ${ }^{\mathrm{T} 790 \mathrm{M}}$ and PI3K $\gamma$ molecular active sites is shown in Figure 5. When compound H10 docked with the 3ika (Figure 5A), we observed that the dimethylamine group extended into the ATP hydrophobic pocket and formed hydrogen bonds with residues LYS-745, and the amino group formed hydrogen bonds with MET-793 residues. Figure 5C shows that the morpholine rings of compound H10 formed hydrogen bonds with the VAL-882 residues in 3L08. Among these, the acrylamide side chain of compound H10 formed hydrogen bonds with the LYS-833 residue in 3L08. This was in line with the combination model we predicted before. The abovementioned SAR (structure-activity relationship) analysis and molecular docking results indicate that compound $\mathbf{H 1 0}$ could be a potentially interesting anticancer agent.

\section{Experimental Section}

\subsection{General Information}

Unless otherwise stated, all reagents used in the experiment were purchased at commercial analytical grade and used directly without further purification. Common solvents (ethanol, methanol, petroleum ether, ethyl acetate, dichloromethane 1,2-dimethoxyethane, etc.) were absolutely anhydrous. All reactions were monitored on a GF254 thin-layer chromatography plate (Laishan Penghan Plastic Industry Store, Yantai, Shandong, China), and spots were visualized at 254 nanometers or 365 nanometers with iodine or light. The target compound $(20 \mathrm{mg}$ ) and $3.5 \mathrm{~mL}$ DMSO formed the corresponding compound solution, and the structure of the target compound was confirmed by ${ }^{1} \mathrm{H}-\mathrm{NMR}$ and ${ }^{13} \mathrm{C}-\mathrm{NMR}$ on a Bruker $400 \mathrm{MHz}$ spectrometer (Bruker Bioscience, Billerica, MA, USA) using tetramethylsilane (TMS) as an internal standard at room temperature (see Supplementary Materials). The target compounds $(0.5 \mathrm{mg})$ and LC-MS methanol were prepared in a $0.5 \mu \mathrm{g} / \mathrm{mL}$ mixed solution, and mass spectrometry (MS) of target compounds was carried out on a Waters High Resolution Quadrupole Time of Flight Tandem Mass Spectrometer (Waters, Milford, MA, USA, Xevo G2-XS Tof). The purity of all compounds was determined using an Agilent 
1260 liquid chromatograph equipped with an Inertex-C18 column. The purity of all target compounds was $\geq 95 \%$.

\subsection{Chemistry}

3.2.1. Representative Procedure for the Synthesis of 2,4-dichloro-6-(thiophen-2-yl)pyrimidine (8)

2,4,6-Trichloropyrimidine 7 (70.0 g, $381.6 \mathrm{mmol})$ and thiophen-2-ylboronic acid (25.2 $\mathrm{g}$, $196.8 \mathrm{mmol}$ ) were coupled by coupling reaction in 1,2-dimethoxyethane and water 5:1 solvent. The above solution was stirred at $90{ }^{\circ} \mathrm{C}$ for about $1.5 \mathrm{~h}$. The reaction was monitored by TLC. After the reaction, the reactant was purified via silica gel column chromatography to obtain compound 8. Yield: $95 \%$; color: yellow; m.p.: $145.1-147.5^{\circ} \mathrm{C} .{ }^{1} \mathrm{H} \mathrm{NMR}(400 \mathrm{MHz}$, DMSO- $\left.d_{6}\right) \delta 7.49(\mathrm{~s}, 1 \mathrm{H}), 7.23(\mathrm{~s}, 1 \mathrm{H}), 7.20(\mathrm{~s}, 1 \mathrm{H}), 7.19(\mathrm{~s}, 1 \mathrm{H})$. TOF MS ES+ $(\mathrm{m} / \mathrm{z}):[\mathrm{M}+\mathrm{H}]^{+}$, calcd for $\mathrm{C}_{8} \mathrm{H}_{4} \mathrm{Cl}_{2} \mathrm{~N}_{2} \mathrm{~S}$ : 232.1100, found, 232.1103 .

3.2.2. Representative Procedure for the Synthesis of

2-chloro-4-(3-nitrophenoxy)-6-(thiophen-2-yl)pyrimidine (9)

Intermediate 8 (19.0 g, $82.3 \mathrm{mmol})$, metanitrophenol $(12.0 \mathrm{~g}, 86.3 \mathrm{mmol})$, and cesium carbonate $(32.0 \mathrm{~g}, 99.5 \mathrm{mmol})$ were dissolved in 1,4-dioxane $(120 \mathrm{~mL})$, and then stirred for $4 \mathrm{~h}$ at room temperature. The completion of the reaction was monitored by TLC. After the reaction, the reaction solvent was removed under reduced pressure to obtain a yellow solid 9. Yield: $91.4 \%$; color: yellow; m.p.: $152-155^{\circ} \mathrm{C} .{ }^{1} \mathrm{H}$ NMR $\left(400 \mathrm{MHz}, \mathrm{DMSO}-d_{6}\right) \delta 8.05$ (s, $1 \mathrm{H}), 8.02(\mathrm{~s}, 1 \mathrm{H}), 7.64(\mathrm{~s}, 1 \mathrm{H}), 7.54(\mathrm{~m}, 1 \mathrm{H}), 7.24(\mathrm{~s}, 1 \mathrm{H}), 7.21(\mathrm{~s}, 1 \mathrm{H}), 7.19(\mathrm{~s}, 1 \mathrm{H}), 7.16(\mathrm{~s}, 1 \mathrm{H})$. TOF MS ES+ $(m / z):[\mathrm{M}+\mathrm{H}]^{+}$, calcd for $\mathrm{C}_{14} \mathrm{H}_{8} \mathrm{ClN}_{3} \mathrm{O}_{3} \mathrm{~S}: 333.7869$, found, 333.7872 .

\subsubsection{Representative Procedure for the Synthesis of $\mathbf{1 0 a}-\mathbf{1 0 b}$}

Intermediate 9 (5.3 g, $16.0 \mathrm{mmol})$, toluene-p-sulfonic acid $(5.6 \mathrm{~g}, 32.5 \mathrm{mmol})$ and different amino side chains $(16.0 \mathrm{mmol})$ were dissolved in acetonitrile $(60 \mathrm{~mL})$ and stirred for $4-5 \mathrm{~h}$ at $100{ }^{\circ} \mathrm{C}$. After the reaction, the reaction solvent was removed under reduced pressure and a large amount of solid precipitated after adding twice the amount of water. The solid was filtered at atmospheric pressure and dried to obtain 10a-10b.

N-(3-methoxyphenyl)-4-(3-nitrophenoxy)-6-(thiophen-2-yl)pyrimidin-2-amine (10a)

Yield: 90.1\%; color: yellow; m.p.: $169.5-172.7^{\circ} \mathrm{C} .{ }^{1} \mathrm{H}$ NMR $\left(400 \mathrm{MHz}, \mathrm{DMSO}-d_{6}\right) \delta$ $8.36(\mathrm{~s}, 1 \mathrm{H}), 8.05(\mathrm{~s}, 1 \mathrm{H}), 7.91(\mathrm{~s}, 1 \mathrm{H}), 7.89(\mathrm{~s}, 1 \mathrm{H}), 7.73(\mathrm{~s}, 1 \mathrm{H}), 7.67(\mathrm{~s}, 1 \mathrm{H}), 7.57-7.54(\mathrm{~m}$, $1 \mathrm{H}), 7.30(\mathrm{dd}, J=7.5,1.5 \mathrm{~Hz}, 1 \mathrm{H}), 7.24(\mathrm{~d}, J=7.4 \mathrm{~Hz}, 1 \mathrm{H}), 7.23-7.16(\mathrm{~m}, 1 \mathrm{H}), 7.14(\mathrm{dt}, J=7.5$, $1.5 \mathrm{~Hz}, 1 \mathrm{H}), 6.89(\mathrm{~s}, 1 \mathrm{H}), 6.57(\mathrm{dt}, J=7.5,1.6 \mathrm{~Hz}, 1 \mathrm{H}), 3.80(\mathrm{~s}, 3 \mathrm{H})$. TOF MS ES+ $(\mathrm{m} / \mathrm{z})$ : $[\mathrm{M}+\mathrm{H}]^{+}$, calcd for $\mathrm{C}_{21} \mathrm{H}_{15} \mathrm{~N}_{3} \mathrm{O}_{4} \mathrm{~S}: 405.0925$, found, 405.0927 .

3-((4-(3-nitrophenoxy)-6-(thiophen-2-yl)pyrimidin-2-yl)amino)benzonitrile (10b)

Yield: 80.7\%; color: yellow; m.p.: $176.1-179.3{ }^{\circ} \mathrm{C} .{ }^{1} \mathrm{H}$ NMR $\left(400 \mathrm{MHz}, \mathrm{DMSO}-d_{6}\right) \delta 8.23$ $(\mathrm{s}, 1 \mathrm{H}), 8.05(\mathrm{dt}, J=7.5,1.6 \mathrm{~Hz}, 1 \mathrm{H}), 7.94(\mathrm{~s}, 1 \mathrm{H}), 7.84(\mathrm{~s}, 1 \mathrm{H}), 7.64(\mathrm{dd}, J=7.3,1.6 \mathrm{~Hz}, 1 \mathrm{H})$, $7.55(\mathrm{t}, J=7.5 \mathrm{~Hz}, 1 \mathrm{H}), 7.45-7.40(\mathrm{~m}, 1 \mathrm{H}), 7.39(\mathrm{~d}, J=7.5 \mathrm{~Hz}, 1 \mathrm{H}), 7.33(\mathrm{dt}, J=7.1,1.7 \mathrm{~Hz}$, $1 \mathrm{H}), 7.24(\mathrm{dd}, J=7.5,1.6 \mathrm{~Hz}, 1 \mathrm{H}), 7.19(\mathrm{t}, J=7.4 \mathrm{~Hz}, 1 \mathrm{H}), 7.14(\mathrm{dt}, J=7.5,1.5 \mathrm{~Hz}, 1 \mathrm{H}), 6.89$ (s, $1 \mathrm{H})$. TOF MS ES+ $(\mathrm{m} / z):[\mathrm{M}+\mathrm{H}]^{+}$, calcd for $\mathrm{C}_{21} \mathrm{H}_{12} \mathrm{~N}_{4} \mathrm{O}_{3} \mathrm{~S}: 401.0746$, found, 401.0749 .

\subsubsection{Representative Procedure for the Synthesis of $\mathbf{1 1 a - 1 1 b}$}

Intermediate 10a-10b (13mmol), ferric chloride $(4.2 \mathrm{~g}, 15.6 \mathrm{mmol})$, and activated carbon $(1.1 \mathrm{~g}, 91.0 \mathrm{mmol})$ were dissolved in ethanol. The solution was warmed to $80{ }^{\circ} \mathrm{C}$, and then water and hydrazine were added $(6.5 \mathrm{~g}, 130 \mathrm{mmol})$ and the solution stirred for $4 \mathrm{~h}$. After the reaction, the reaction solvent was removed under reduced pressure, saturated sodium bicarbonate aqueous solution was added, and the solution was filtered to generate 11a-11b.

4-(3-aminophenoxy)-N-(3-methoxyphenyl)-6-(thiophen-2-yl)pyrimidin-2-amine (11a)

Yield: 78.3\%; color: yellow; m.p.: 192.5-195.4 ${ }^{\circ} \mathrm{C} .{ }^{1} \mathrm{H}$ NMR $\left(400 \mathrm{MHz}, \mathrm{DMSO}-d_{6}\right) \delta$ $8.46(\mathrm{~s}, 1 \mathrm{H}), 7.83(\mathrm{~s}, 1 \mathrm{H}), 7.74(\mathrm{~s}, 1 \mathrm{H}), 7.66(\mathrm{~s}, 1 \mathrm{H}), 7.27(\mathrm{dt}, J=6.3,4.5 \mathrm{~Hz}, 1 \mathrm{H}), 7.23(\mathrm{dt}$, $J=6.8,3.6 \mathrm{~Hz}, 1 \mathrm{H}), 7.22-7.20(\mathrm{~m}, 1 \mathrm{H}), 7.17(\mathrm{~s}, 1 \mathrm{H}), 7.02(\mathrm{~s}, 1 \mathrm{H}), 6.91(\mathrm{~s}, 1 \mathrm{H}), 6.83(\mathrm{~s}, 1 \mathrm{H})$, 
$6.57(\mathrm{~s}, 1 \mathrm{H}), 6.17(\mathrm{~s}, 1 \mathrm{H}), 5.06(\mathrm{~s}, 2 \mathrm{H}), 3.80(\mathrm{~s}, 3 \mathrm{H})$. TOF MS ES+ $(\mathrm{m} / \mathrm{z}):[\mathrm{M}+\mathrm{H}]^{+}$, calcd for $\mathrm{C}_{21} \mathrm{H}_{17} \mathrm{~N}_{3} \mathrm{O}_{2} \mathrm{~S}: 376.1405$, found, 376.1408 .

3-((4-(3-aminophenoxy)-6-(thiophen-2-yl)pyrimidin-2-yl)amino)benzonitrile (11b)

Yield: $71.1 \%$; color: yellow; m.p.: $189.7-193.5{ }^{\circ} \mathrm{C} .{ }^{1} \mathrm{H}$ NMR $\left(400 \mathrm{MHz}, \mathrm{DMSO}-d_{6}\right) \delta$ $8.23(\mathrm{~s}, 1 \mathrm{H}), 7.83(\mathrm{~s}, 1 \mathrm{H}), 7.66(\mathrm{~s}, 1 \mathrm{H}), 7.42(\mathrm{dt}, J=10.2,9.1 \mathrm{~Hz}, 1 \mathrm{H}), 7.40(\mathrm{dt}, J=8.7,5.6 \mathrm{~Hz}$, $1 \mathrm{H}), 7.33(\mathrm{~s}, 1 \mathrm{H}), 7.25(\mathrm{~s}, 1 \mathrm{H}), 7.21(\mathrm{~s}, 1 \mathrm{H}), 7.19(\mathrm{~s}, 1 \mathrm{H}), 7.02(\mathrm{~s}, 1 \mathrm{H}), 6.92(\mathrm{~s}, 1 \mathrm{H}), 6.83(\mathrm{~s}, 1 \mathrm{H})$, $6.17(\mathrm{~s}, 1 \mathrm{H}), 5.06(\mathrm{~s}, 2 \mathrm{H})$. TOF MS ES+ $(\mathrm{m} / \mathrm{z}):[\mathrm{M}+\mathrm{H}]^{+}$, calcd for $\mathrm{C}_{21} \mathrm{H}_{14} \mathrm{~N}_{4} \mathrm{OS}: 371.0983$, found, 371.0980 .

\subsubsection{Representative Procedure for the Synthesis of Target Compounds H1-H8}

Intermediate 11a-11b $(1.5 \mathrm{mmol})$ and bicarbonate $(0.25 \mathrm{~g}, 3 \mathrm{mmol})$ were dissolved in dichloromethane and reacted with different amide side chains under ice-bath conditions. The completion of the reaction was monitored by TLC. The reactant was purified via silica gel column chromatography to obtain the target compounds H1-H8 with high purity.

\subsubsection{Representative Procedure for the Synthesis of 12-16}

The specific operation was carried out according to our previous research and the physical data were in agreement with reported values [18].

\subsubsection{Representative Procedure for the Synthesis of $\mathbf{1 7 a - 1 7 b}$}

Intermediate 16 ( $0.5 \mathrm{~g}, 1.5 \mathrm{mmol})$, different amino side chains $(3 \mathrm{mmol})$, and two drops of N,N-diisopropylethylamine (DIPEA) were dissolved in isopropanol $(50 \mathrm{~mL})$ and stirred for $1 \mathrm{~h}$ at $75^{\circ} \mathrm{C}$. After the reaction, the reaction solvent was removed under reduced pressure to obtain a yellow liquid $\mathbf{1 7} \mathbf{a}-\mathbf{1 7} \mathbf{b}$.

1-(5-(4-chloro-6-morpholino-1,3,5-triazin-2-yl)thiophen-2-yl)-N,N-dimethylmethanamine (17a)

Yield: 85.1\%; color: yellow; m.p.: $174.2-175.4{ }^{\circ} \mathrm{C}$. TOF MS ES+ $(m / z):[\mathrm{M}+\mathrm{H}]^{+}$, calcd for $\mathrm{C}_{14} \mathrm{H}_{18} \mathrm{ClN}_{5} \mathrm{OS}$ : 339.9370 , found, 339.9373 .

$\mathrm{N}$-((5-(4-chloro-6-morpholino-1,3,5-triazin-2-yl)thiophen-2-yl)methyl)-N-ethylethanamine (17b)

Yield: $82.2 \%$; color: yellow; m.p.: $163.8-165.1{ }^{\circ} \mathrm{C}$. TOF MS ES+ $(\mathrm{m} / \mathrm{z}):[\mathrm{M}+\mathrm{H}]^{+}$, calcd for $\mathrm{C}_{16} \mathrm{H}_{22} \mathrm{ClN}_{5} \mathrm{OS}$ : 368.2436, found, 368.2433.

\subsubsection{Representative Procedure for the Synthesis of $\mathbf{1 8 a}-\mathbf{1 8 b}$}

Intermediate 17a-17b $(1 \mathrm{mmol})$, 3-aminophenol $(0.1 \mathrm{~g}, 1.1 \mathrm{mmol})$, and tert-butoxide $(0.22 \mathrm{~g}, 2 \mathrm{mmol})$ were dissolved in THF and then stirred for $1 \mathrm{~h}$ under ice-bath conditions. The reaction was monitored by TLC. After the reaction, the reaction solvent was removed under reduced pressure to obtain a yellow liquid $\mathbf{1 8 a} \mathbf{a} \mathbf{- 1 8 b}$.

3-((4-(5-((dimethylamino)methyl)thiophen-2-yl)-6-morpholino-1,3,5-triazin-2-yl)oxy)aniline (18a)

Yield: $78.2 \%$; color: yellow; m.p.: $179.3-182.9{ }^{\circ} \mathrm{C}$. TOF MS ES+ $(\mathrm{m} / \mathrm{z}):[\mathrm{M}+\mathrm{H}]^{+}$, calcd for $\mathrm{C}_{20} \mathrm{H}_{24} \mathrm{~N}_{6} \mathrm{O}_{2} \mathrm{~S}: 413.5214$, found, 413.5211.

3-((4-(5-((diethylamino)methyl)thiophen-2-yl)-6-morpholino-1,3,5-triazin-2-yl)oxy)aniline (18b)

Yield: $85.1 \%$; color: yellow; m.p.: $178.4-181.5^{\circ} \mathrm{C}$. TOF MS ES+ $(\mathrm{m} / \mathrm{z}):[\mathrm{M}+\mathrm{H}]^{+}$, calcd for $\mathrm{C}_{22} \mathrm{H}_{28} \mathrm{~N}_{6} \mathrm{O}_{2} \mathrm{~S}: 441.6275$, found, 441.6277 .

\subsubsection{Representative Procedure for the Synthesis of Target Compounds H9-H16} H1-H8.

The synthesis of target compounds H9-H16 was similar to that of target compounds

N-(3-((2-((3-cyanophenyl)amino)-6-(thiophen-2-yl)pyrimidin-4-yl)oxy)phenyl)acrylamide (H1). Yield: 40.3\%; color: yellow; m.p.: 197.2-199.4 ${ }^{\circ} \mathrm{C} ;{ }^{1} \mathrm{H}$ NMR (400 MHz, DMSO- $\left.d_{6}\right) \delta 10.34$ $(\mathrm{s}, 1 \mathrm{H}), 9.95(\mathrm{~s}, 1 \mathrm{H}), 8.07(\mathrm{~s}, 1 \mathrm{H}), 7.85(\mathrm{~s}, 2 \mathrm{H}), 7.70(\mathrm{~d}, J=6.3 \mathrm{~Hz}, 1 \mathrm{H}), 7.51(\mathrm{~d}, J=8.3 \mathrm{~Hz}$, $1 \mathrm{H}), 7.46(\mathrm{t}, J=8.1 \mathrm{~Hz}, 2 \mathrm{H}), 7.33(\mathrm{~s}, 2 \mathrm{H}), 7.28-7.24(\mathrm{~m}, 1 \mathrm{H}), 7.16(\mathrm{~s}, 1 \mathrm{H}), 7.03-6.99(\mathrm{~m}, 1 \mathrm{H})$, $6.42(\mathrm{dd}, J=16.9,10.1 \mathrm{~Hz}, 1 \mathrm{H}), 6.27(\mathrm{dd}, J=16.9,2.0 \mathrm{~Hz}, 1 \mathrm{H}), 5.79-5.74(\mathrm{~m}, 1 \mathrm{H})$. TOF MS ES+ $(\mathrm{m} / z):[\mathrm{M}+\mathrm{H}]^{+}$, calcd for $\mathrm{C}_{25} \mathrm{H}_{19} \mathrm{~N}_{5} \mathrm{O}_{2} \mathrm{~S}: 456.3863$, found, 456.3864 . 
(E)-N-(3-((2-((3-cyanophenyl)amino)-6-(thiophen-2-yl)pyrimidin-4-yl)oxy)phenyl)but-2-enamide (H2). Yield: 58.3\%; color: yellow; m.p.: 201.2-205.9 ${ }^{\circ} \mathrm{C} ;{ }^{1} \mathrm{H}$ NMR (400 MHz, DMSO- $\left.d_{6}\right) \delta$ $10.13(\mathrm{~s}, 1 \mathrm{H}), 9.95(\mathrm{~s}, 1 \mathrm{H}), 8.08(\mathrm{~d}, J=5.8 \mathrm{~Hz}, 2 \mathrm{H}), 7.85(\mathrm{~d}, J=5.1 \mathrm{~Hz}, 2 \mathrm{H}), 7.68(\mathrm{~d}, J=10.9 \mathrm{~Hz}$, $1 \mathrm{H}), 7.47(\mathrm{~d}, J=8.2 \mathrm{~Hz}, 1 \mathrm{H}), 7.42(\mathrm{~d}, J=7.9 \mathrm{~Hz}, 1 \mathrm{H}), 7.34(\mathrm{~s}, 2 \mathrm{H}), 7.27-7.24(\mathrm{~m}, 1 \mathrm{H}), 7.16$ (s, $1 \mathrm{H}), 6.99(\mathrm{~d}, J=8.1 \mathrm{~Hz}, 1 \mathrm{H}), 6.80(\mathrm{dd}, J=15.3,7.6 \mathrm{~Hz}, 1 \mathrm{H}), 6.14(\mathrm{~d}, J=15.3 \mathrm{~Hz}, 1 \mathrm{H})$, $1.86(\mathrm{~d}, J=7.0 \mathrm{~Hz}, 3 \mathrm{H})$. TOF MS ES+ $(\mathrm{m} / \mathrm{z}):[\mathrm{M}+\mathrm{H}]^{+}$, calcd for $\mathrm{C}_{25} \mathrm{H}_{19} \mathrm{~N}_{5} \mathrm{O}_{2} \mathrm{~S}: 454.5743$, found, 454.5746 .

N-(3-((2-((3-cyanophenyl)amino)-6-(thiophen-2-yl)pyrimidin-4-yl)oxy)phenyl)-3-methylbut-2-enamide (H3). Yield: 66.3\%; color: yellow; m.p.: 215.5-218.7 ${ }^{\circ} \mathrm{C} ;{ }^{1} \mathrm{H}$ NMR (400 MHz, DMSO- $\left.d_{6}\right)$ $\delta 10.01(\mathrm{~s}, 1 \mathrm{H}), 9.95(\mathrm{~s}, 1 \mathrm{H}), 8.07(\mathrm{~d}, J=3.8 \mathrm{~Hz}, 1 \mathrm{H}), 7.85(\mathrm{~d}, J=4.9 \mathrm{~Hz}, 2 \mathrm{H}), 7.67(\mathrm{~s}, 1 \mathrm{H})$, 7.42-7.40 (m, 3H), $7.34(\mathrm{~s}, 2 \mathrm{H}), 7.27-7.24(\mathrm{~m}, 1 \mathrm{H}), 7.15(\mathrm{~s}, 1 \mathrm{H}), 6.96(\mathrm{~d}, J=8.1 \mathrm{~Hz}, 1 \mathrm{H})$, $5.86(\mathrm{~s}, 1 \mathrm{H}), 2.12(\mathrm{~s}, 3 \mathrm{H}), 1.85(\mathrm{~s}, 3 \mathrm{H})$. TOF MS ES+ $(\mathrm{m} / \mathrm{z}):[\mathrm{M}+\mathrm{H}]^{+}$, calcd for $\mathrm{C}_{25} \mathrm{H}_{19} \mathrm{~N}_{5} \mathrm{O}_{2} \mathrm{~S}$ : 468.5745 , found, 468.5747 .

(E)-N-(3-((2-((3-cyanophenyl)amino)-6-(thiophen-2-yl)pyrimidin-4-yl)oxy)phenyl)hex-2-enamide (H4). Yield: 48.6\%; color: yellow; m.p.: 209.6-211.4 ${ }^{\circ} \mathrm{C} ;{ }^{1} \mathrm{H}$ NMR (400 MHz, DMSO- $\left.d_{6}\right) \delta$ $10.15(\mathrm{~s}, 1 \mathrm{H}), 9.95(\mathrm{~s}, 1 \mathrm{H}), 8.07(\mathrm{~d}, J=3.7 \mathrm{~Hz}, 1 \mathrm{H}), 7.85(\mathrm{~d}, J=5.0 \mathrm{~Hz}, 2 \mathrm{H}), 7.68(\mathrm{~s}, 1 \mathrm{H}), 7.48(\mathrm{~d}$, $J=8.4 \mathrm{~Hz}, 1 \mathrm{H}), 7.42(\mathrm{t}, J=8.0 \mathrm{~Hz}, 2 \mathrm{H}), 7.34(\mathrm{~s}, 2 \mathrm{H}), 7.26(\mathrm{dd}, J=5.0,3.8 \mathrm{~Hz}, 1 \mathrm{H}), 7.16(\mathrm{~s}$, $1 \mathrm{H}), 6.98(\mathrm{~d}, J=7.9 \mathrm{~Hz}, 1 \mathrm{H}), 6.82-6.76(\mathrm{~m}, 1 \mathrm{H}), 6.10(\mathrm{~d}, J=15.4 \mathrm{~Hz}, 1 \mathrm{H}), 2.18(\mathrm{~d}, J=7.0 \mathrm{~Hz}$, $2 \mathrm{H}), 1.46(\mathrm{~d}, J=7.3 \mathrm{~Hz}, 2 \mathrm{H}), 0.90(\mathrm{~d}, J=3.5 \mathrm{~Hz}, 3 \mathrm{H})$. TOF MS ES+ $(m / z):[\mathrm{M}+\mathrm{H}]^{+}$, calcd for $\mathrm{C}_{25} \mathrm{H}_{19} \mathrm{~N}_{5} \mathrm{O}_{2} \mathrm{~S}: 482.3266$, found, 482.3265 .

N-(3-((2-((3-cyanophenyl)amino)-6-(thiophen-2-yl)pyrimidin-4-yl)oxy)phenyl)-2-fluoroacrylamide (H5). Yield: 33.1\%; color: yellow; m.p.: 222.9-226.8 ${ }^{\circ} \mathrm{C} ;{ }^{1} \mathrm{H}$ NMR (400 MHz, DMSO- $\left.d_{6}\right) \delta$ $10.46(\mathrm{~s}, 1 \mathrm{H}), 9.97(\mathrm{~s}, 1 \mathrm{H}), 8.08(\mathrm{~d}, J=4.0 \mathrm{~Hz}, 1 \mathrm{H}), 7.86(\mathrm{~d}, J=5.3 \mathrm{~Hz}, 1 \mathrm{H}), 7.70(\mathrm{~d}, J=10.7 \mathrm{~Hz}$, $2 \mathrm{H}), 7.49(\mathrm{t}, J=8.0 \mathrm{~Hz}, 2 \mathrm{H}), 7.34(\mathrm{~s}, 2 \mathrm{H}), 7.27(\mathrm{~d}, J=4.7 \mathrm{~Hz}, 1 \mathrm{H}), 7.17(\mathrm{~s}, 1 \mathrm{H}), 7.09(\mathrm{~d}$, $J=8.6 \mathrm{~Hz}, 1 \mathrm{H}), 5.78(\mathrm{~d}, J=3.7 \mathrm{~Hz}, 1 \mathrm{H}), 5.65(\mathrm{~s}, 1 \mathrm{H}), 5.48-5.41(\mathrm{~m}, 1 \mathrm{H})$. TOF MS ES+ $(\mathrm{m} / \mathrm{z})$ : $[\mathrm{M}+\mathrm{H}]^{+}$, calcd for $\mathrm{C}_{24} \mathrm{H}_{16} \mathrm{FN}_{5} \mathrm{O}_{2} \mathrm{~S}: 458.4987$, found, 458.4989 .

(E)-N-(3-((2-((3-cyanophenyl)amino)-6-(thiophen-2-yl)pyrimidin-4-yl)oxy)phenyl)-4-methylpent2-enamide (H6). Yield: 51.8\%; color: yellow; m.p.: 223.1-225.4 ${ }^{\circ} \mathrm{C}{ }^{1} \mathrm{H}$ NMR $(400 \mathrm{MHz}$, DMSO-d $\left.{ }_{6}\right) \delta 10.19(\mathrm{~s}, 1 \mathrm{H}), 9.94(\mathrm{~s}, 1 \mathrm{H}), 8.06(\mathrm{~d}, J=3.8 \mathrm{~Hz}, 1 \mathrm{H}), 7.84(\mathrm{~d}, J=5.2 \mathrm{~Hz}, 2 \mathrm{H})$, $7.68(\mathrm{~d}, J=4.5 \mathrm{~Hz}, 1 \mathrm{H}), 7.48(\mathrm{~d}, J=8.3 \mathrm{~Hz}, 1 \mathrm{H}), 7.42(\mathrm{t}, J=8.1 \mathrm{~Hz}, 1 \mathrm{H}), 7.33(\mathrm{~s}, 2 \mathrm{H}), 7.25(\mathrm{t}$, $J=4.4 \mathrm{~Hz}, 1 \mathrm{H}), 7.15(\mathrm{~s}, 1 \mathrm{H}), 6.98(\mathrm{~d}, J=8.0 \mathrm{~Hz}, 1 \mathrm{H}), 6.81(\mathrm{~d}, J=6.3 \mathrm{~Hz}, 1 \mathrm{H}), 6.79-6.74(\mathrm{~m}$, $1 \mathrm{H}), 6.06(\mathrm{~d}, J=15.4 \mathrm{~Hz}, 1 \mathrm{H}), 2.44(\mathrm{dd}, J=13.1,6.6 \mathrm{~Hz}, 1 \mathrm{H}), 1.03(\mathrm{~d}, J=6.5 \mathrm{~Hz}, 6 \mathrm{H})$. TOF MS $\mathrm{ES}+(\mathrm{m} / \mathrm{z}):[\mathrm{M}+\mathrm{H}]^{+}$, calcd for $\mathrm{C}_{27} \mathrm{H}_{23} \mathrm{~N}_{5} \mathrm{O}_{2} \mathrm{~S}: 482.5866$, found, 482.5868 .

(E)-N-(3-((2-((3-methoxyphenyl)amino)-6-(thiophen-2-yl)pyrimidin-4-yl)oxy)phenyl)but-2-enamide (H7). Yield: 43.7\%; color: yellow; m.p.: $231.7-234.3{ }^{\circ} \mathrm{C} ;{ }^{1} \mathrm{H}$ NMR (400 MHz, DMSO- $\left.d_{6}\right)$ $\delta 10.15(\mathrm{~s}, 1 \mathrm{H}), 9.43(\mathrm{~s}, 1 \mathrm{H}), 8.00(\mathrm{~s}, 1 \mathrm{H}), 7.23(\mathrm{~s}, 2 \mathrm{H}), 6.76(\mathrm{~d}, J=6.9 \mathrm{~Hz}, 5 \mathrm{H}), 6.08(\mathrm{~d}$, $J=15.2 \mathrm{~Hz}, 6 \mathrm{H}), 3.67(\mathrm{~s}, 3 \mathrm{H}), 1.93(\mathrm{~d}, J=7.8 \mathrm{~Hz}, 3 \mathrm{H}) .{ }^{13} \mathrm{C}$ NMR $\left(101 \mathrm{MHz}, \mathrm{DMSO}-d_{6}\right) \delta$ $170.28,163.61,163.02,159.31,155.14,154.13,140.54,140.28,139.03,133.31,132.43,130.17$, $129.72,128.50,127.84,126.10,120.67,116.37,115.97,113.36,112.62,55.11,17.41$. TOF MS $\mathrm{ES}+(\mathrm{m} / z):[\mathrm{M}+\mathrm{H}]^{+}$, calcd for $\mathrm{C}_{25} \mathrm{H}_{22} \mathrm{~N}_{4} \mathrm{O}_{3} \mathrm{~S}: 459.5356$, found, 459.5359 .

(E)-N-(3-((2-((3-methoxyphenyl)amino)-6-(thiophen-2-yl)pyrimidin-4-yl)oxy)phenyl)-4-methylpent2-enamide (H8). Yield: 22.6\%; color: yellow; m.p.: 217.9-219.1 ${ }^{\circ} \mathrm{C}$; ${ }^{1} \mathrm{H}$ NMR $400 \mathrm{MHz}$, DMSO- $\left.d_{6}\right) \delta 9.83(\mathrm{~s}, 2 \mathrm{H}), 7.55(\mathrm{~d}, J=8.8 \mathrm{~Hz}, 4 \mathrm{H}), 6.87(\mathrm{~d}, J=8.9 \mathrm{~Hz}, 5 \mathrm{H}), 6.75(\mathrm{dd}, J=15.4$, $6.4 \mathrm{~Hz}, 3 \mathrm{H}), 6.05(\mathrm{~s}, 1 \mathrm{H}), 6.01(\mathrm{~s}, 1 \mathrm{H}), 3.72(\mathrm{~s}, 3 \mathrm{H}), 1.06(\mathrm{~s}, 7 \mathrm{H})$. TOF MS ES+ $(\mathrm{m} / \mathrm{z}):[\mathrm{M}+\mathrm{H}]^{+}$, calcd for $\mathrm{C}_{27} \mathrm{H}_{26} \mathrm{~N}_{4} \mathrm{O}_{3} \mathrm{~S}$ : 487.6124 , found, 487.6126 .

N-(3-((4-(5-((dimethylamino)methyl)thiophen-2-yl)-6-morpholino-1,3,5-triazin-2-yl)oxy)phenyl)acrylamide (H9). Yield: 76.8\%; color: yellow; m.p.: 224.9-226.1 ${ }^{\circ} \mathrm{C} ;{ }^{1} \mathrm{H}$ NMR (400 MHz, DMSO- $\left.d_{6}\right) \delta$ $9.39(\mathrm{~s}, 1 \mathrm{H}), 7.25(\mathrm{~s}, 2 \mathrm{H}), 7.08(\mathrm{~s}, 1 \mathrm{H}), 7.06(\mathrm{~s}, 1 \mathrm{H}), 7.03(\mathrm{~s}, 1 \mathrm{H}), 7.01(\mathrm{~s}, 1 \mathrm{H}), 6.48-6.47(\mathrm{~m}, 1 \mathrm{H})$, 6.25-6.21 (m, 1H), $5.74(\mathrm{~s}, 1 \mathrm{H}), 3.64(\mathrm{~s}, 4 \mathrm{H}), 3.58(\mathrm{~s}, 4 \mathrm{H}), 3.02(\mathrm{~s}, 2 \mathrm{H}), 1.24(\mathrm{~s}, 6 \mathrm{H})$. TOF MS $\mathrm{ES}+(\mathrm{m} / z):[\mathrm{M}+\mathrm{H}]^{+}$, calcd for $\mathrm{C}_{23} \mathrm{H}_{26} \mathrm{~N}_{6} \mathrm{O}_{3} \mathrm{~S}: 466.5668$, found, 466.5670 . 
(E)-N-(3-((4-(5-((dimethylamino)methyl)thiophen-2-yl)-6-morpholino-1,3,5-triazin-2-yl)oxy)phenyl)but2-enamide (H10). Yield: 63.5\%; color: yellow; m.p.: $202.4-203.7^{\circ} \mathrm{C}$; ${ }^{1} \mathrm{H}$ NMR $((400 \mathrm{MHz}$, DMSO-d 6$) \delta 9.65(\mathrm{~s}, 1 \mathrm{H}), 9.38(\mathrm{~s}, 2 \mathrm{H}), 7.25(\mathrm{~s}, 1 \mathrm{H}), 7.05(\mathrm{~s}, 2 \mathrm{H}), 6.46(\mathrm{~s}, 1 \mathrm{H}), 5.75(\mathrm{~s}, 1 \mathrm{H}), 5.48(\mathrm{~s}$, 1H), $3.64(\mathrm{~s}, 4 \mathrm{H}), 3.58(\mathrm{~s}, 4 \mathrm{H}), 3.02(\mathrm{~s}, 2 \mathrm{H}), 1.93(\mathrm{~s}, 6 \mathrm{H}), 1.23(\mathrm{~s}, 3 \mathrm{H}) .{ }^{13} \mathrm{C} \mathrm{NMR}(101 \mathrm{MHz}$, DMSO-d $\left.{ }_{6}\right) \delta 170.01,169.89,168.95,163.76,163.12,157.33,157.13,146.17,142.55,142.09$, $136.74,136.45,134.96,128.48,124.20,121.58,117.67,114.48,113.04,58.14,36.37,35.08,32.23$, 24.75. TOF MS ES+ (m/z): $[\mathrm{M}+\mathrm{H}]^{+}$, calcd for $\mathrm{C}_{24} \mathrm{H}_{28} \mathrm{~N}_{6} \mathrm{O}_{3} \mathrm{~S}: 480.5873$, found, 480.5875 .

N-(3-((4-(5-((dimethylamino)methyl)thiophen-2-yl)-6-morpholino-1,3,5-triazin-2-yl)oxy)phenyl)-3methylbut-2-enamide (H11). Yield: 84.5\%; color: yellow; m.p.: 198.7-199.8 ${ }^{\circ} \mathrm{C} ;{ }^{1} \mathrm{H}$ NMR $\left(400 \mathrm{MHz}, \mathrm{DMSO}-d_{6}\right) \delta 9.30(\mathrm{~s}, 1 \mathrm{H}), 7.76(\mathrm{~s}, 1 \mathrm{H}), 7.23(\mathrm{~s}, 1 \mathrm{H}), 6.98(\mathrm{~s}, 2 \mathrm{H}), 6.77(\mathrm{~s}, 1 \mathrm{H}), 6.42(\mathrm{~s}$, $1 \mathrm{H}), 5.99(\mathrm{~s}, 1 \mathrm{H}), 3.08-3.15(\mathrm{~m}, 10 \mathrm{H}), 2.21(\mathrm{~s}, 9 \mathrm{H}), 1.84(\mathrm{~s}, 3 \mathrm{H})$. TOF MS ES+ $(\mathrm{m} / \mathrm{z}):[\mathrm{M}+\mathrm{H}]^{+}$, calcd for $\mathrm{C}_{24} \mathrm{H}_{28} \mathrm{~N}_{6} \mathrm{O}_{3} \mathrm{~S}$ : 482.6257, found, 482.6256 .

(E)-N-(3-((4-(5-((dimethylamino)methyl)thiophen-2-yl)-6-morpholino-1,3,5-triazin-2-yl)oxy)phenyl)4-methylpent-2-enamide (H12). Yield: 78.5\%; color: yellow; m.p.: 199.7-201.3 ${ }^{\circ} \mathrm{C} ;{ }^{1} \mathrm{H}$ NMR $\left(400 \mathrm{MHz}, \mathrm{DMSO}-d_{6}\right) \delta 9.85(\mathrm{~s}, 1 \mathrm{H}), 9.39(\mathrm{~s}, 1 \mathrm{H}), 7.76(\mathrm{~s}, 1 \mathrm{H}), 7.28(\mathrm{~s}, 1 \mathrm{H}), 7.07$ (m, $2 \mathrm{H}), 6.83(\mathrm{~m}, 1 \mathrm{H}), 6.46(\mathrm{~s}, 1 \mathrm{H}), 6.10(\mathrm{~m}, 1 \mathrm{H}), 3.64(\mathrm{~s}, 4 \mathrm{H}), 3.58(\mathrm{~s}, 4 \mathrm{H}), 3.02(\mathrm{~s}, 2 \mathrm{H})$, 1.93(s, 7H), $1.06(\mathrm{~s}, 6 \mathrm{H})$. TOF MS ES+ $(\mathrm{m} / \mathrm{z}):[\mathrm{M}+\mathrm{H}]^{+}$, calcd for $\mathrm{C}_{26} \mathrm{H}_{32} \mathrm{~N}_{6} \mathrm{O}_{3} \mathrm{~S}: 508.6263$, found, 508.6266 .

N-(3-((4-(5-((diethylamino)methyl)thiophen-2-yl)-6-morpholino-1,3,5-triazin-2-yl)oxy)phenyl) methacrylamide (H13). Yield: 64.7\%; color: yellow; m.p.: $240.7-243.5{ }^{\circ} \mathrm{C} ;{ }^{1} \mathrm{H} \mathrm{NMR}(400 \mathrm{MHz}$, DMSO-d 6$) \delta 9.71(\mathrm{~s}, 1 \mathrm{H}), 7.78(\mathrm{~s}, 1 \mathrm{H}), 7.35(\mathrm{~s}, 1 \mathrm{H}), 6.97(\mathrm{~s}, 1 \mathrm{H}), 6.54(\mathrm{~s}, 1 \mathrm{H}), 6.02(\mathrm{~s}, 1 \mathrm{H}), 5.82(\mathrm{~s}$, $1 \mathrm{H}), 5.60(\mathrm{~s}, 1 \mathrm{H}), 5.51(\mathrm{~s}, 1 \mathrm{H}), 3.75(\mathrm{~s}, 6 \mathrm{H}), 1.98(\mathrm{~s}, 4 \mathrm{H}), 1.89(\mathrm{~s}, 4 \mathrm{H}), 1.16(\mathrm{~d}, 3 \mathrm{H}), 1.00(\mathrm{~m}$, $6 \mathrm{H})$. TOF MS ES+ (m/z): $[\mathrm{M}+\mathrm{H}]^{+}$, calcd for $\mathrm{C}_{26} \mathrm{H}_{32} \mathrm{~N}_{6} \mathrm{O}_{3} \mathrm{~S}: 509.6956$, found, 509.6953.

(E)-N-(3-((4-(5-((diethylamino)methyl)thiophen-2-yl)-6-morpholino-1,3,5-triazin-2-yl)oxy)phenyl)but2-enamide (H14). Yield: 35.8\%; color: yellow; m.p.: $189.7-192.1{ }^{\circ} \mathrm{C} ;{ }^{1} \mathrm{H}$ NMR $(400 \mathrm{MHz}$, DMSO-d $\left.{ }_{6}\right) \delta 9.84(\mathrm{~s}, 1 \mathrm{H}), 7.74(\mathrm{~s}, 1 \mathrm{H}), 7.29(\mathrm{~s}, 1 \mathrm{H}), 6.96(\mathrm{~s}, 1 \mathrm{H}), 6.78(\mathrm{~d}, J=6.9 \mathrm{~Hz}, 1 \mathrm{H}), 6.15(\mathrm{~s}$, $1 \mathrm{H}), 6.11(\mathrm{~s}, 1 \mathrm{H}), 5.82(\mathrm{~s}, 1 \mathrm{H}), 5.78(\mathrm{~s}, 1 \mathrm{H}), 3.74(\mathrm{~s}, 6 \mathrm{H}), 1.83(\mathrm{~m}, 4 \mathrm{H}), 1.14(\mathrm{~d}, 4 \mathrm{H}), 0.98(\mathrm{~m}$, 9H). TOF MS ES+ $(m / z):[\mathrm{M}+\mathrm{H}]^{+}$, calcd for $\mathrm{C}_{26} \mathrm{H}_{32} \mathrm{~N}_{6} \mathrm{O}_{3} \mathrm{~S}: 509.6933$, found, 509.6931 .

N-(3-((4-(5-((diethylamino)methyl)thiophen-2-yl)-6-morpholino-1,3,5-triazin-2-yl)oxy)phenyl)-3methylbut-2-enamide (H15). Yield: 41.5\%; color: yellow; m.p.: 215.2-217.1 ${ }^{\circ} \mathrm{C} ;{ }^{1} \mathrm{H}$ NMR $\left(400 \mathrm{MHz}, \mathrm{DMSO}-d_{6}\right) \delta 9.71(\mathrm{~s}, 1 \mathrm{H}), 7.27(\mathrm{~s}, 1 \mathrm{H}), 7.06(\mathrm{~s}, 1 \mathrm{H}), 7.00(\mathrm{~s}, 1 \mathrm{H}), 6.45(\mathrm{~s}, 1 \mathrm{H}), 6.02(\mathrm{~s}$, $1 \mathrm{H}), 5.87(\mathrm{~s}, 1 \mathrm{H}), 5.63(\mathrm{~s}, 1 \mathrm{H}), 3.74(\mathrm{~s}, 6 \mathrm{H}), 2.15(\mathrm{~s}, 4 \mathrm{H}), 1.86(\mathrm{~s}, 4 \mathrm{H}), 1.14(\mathrm{~s}, 6 \mathrm{H}), 0.99(\mathrm{~s}, 6 \mathrm{H})$ TOF MS ES+ $(\mathrm{m} / \mathrm{z}):[\mathrm{M}+\mathrm{H}]^{+}$, calcd for $\mathrm{C}_{26} \mathrm{H}_{32} \mathrm{~N}_{6} \mathrm{O}_{3} \mathrm{~S}: 523.8974$, found, 523.8971 .

(E)-N-(3-((4-(5-((diethylamino)methyl)thiophen-2-yl)-6-morpholino-1,3,5-triazin-2-yl)oxy)phenyl)4-methylpent-2-enamide (H16). Yield: 26.4\%; color: yellow; m.p.: 222.9.2-226.4 ${ }^{\circ} \mathrm{C} ;{ }^{1} \mathrm{H}$ NMR $\left(400 \mathrm{MHz}, \mathrm{DMSO}-d_{6}\right) \delta 9.88(\mathrm{~s}, 1 \mathrm{H}), 7.75(\mathrm{~s}, 1 \mathrm{H}), 7.30(\mathrm{~s}, 1 \mathrm{H}), 7.05(\mathrm{~s}, 1 \mathrm{H}), 6.79(\mathrm{~s}, 1 \mathrm{H}), 6.48(\mathrm{~s}$, $1 \mathrm{H}), 6.10(\mathrm{~s}, 1 \mathrm{H}), 6.07(\mathrm{~s}, 1 \mathrm{H}), 3.72(\mathrm{~s}, 6 \mathrm{H}), 1.14(\mathrm{~s}, 10 \mathrm{H}), 1.05(\mathrm{~d}, J=6.7 \mathrm{~Hz}, 12 \mathrm{H})$. TOF MS $\mathrm{ES}+(\mathrm{m} / z):[\mathrm{M}+\mathrm{H}]^{+}$, calcd for $\mathrm{C}_{26} \mathrm{H}_{32} \mathrm{~N}_{6} \mathrm{O}_{3} \mathrm{~S}: 536.6475$, found, 536.6473 .

\subsection{EGFR and PI3K $\alpha$ Kinase Assay}

The potent compounds $\mathbf{H 7}$ and $\mathbf{H 1 0}$ were tested for their activities against EGFR ${ }^{\mathrm{T} 790 \mathrm{M} / \mathrm{L} 858 \mathrm{R}}$ and PI3K $\alpha$ enzyme using the Kinase-Glo Luminescent Kinase Assay, with olmutinib as a positive control. The specific operation was carried out according to our previous research $[19,20]$.

\subsection{Cytotoxicity Assay In Vitro}

The in vitro cytotoxic activities of all compounds H1-H16 were evaluated with A549, H1975, LO2, and MCF-7 cell lines using the standard MTT assay, with olmutinib as a positive control [21]. 


\subsection{Docking Studies}

The three-dimensional structure of EGFR (PDB code: 4azu, 3L08) was obtained from the RCSB Protein Data Bank. We used AutoDock 4.2 software (The Scripps Research Institute, USA) for molecular docking. The docking process mainly included fixing the exact residues, adding hydrogen atoms, removing irrelevant water molecules, adding charges, etc. All the docking results were processed and modified in Open-Source PyMOL 1.8. $x$ software (https: / / pymol.org (accessed on 25 March 2021).).

\section{Conclusions}

In summary, two series of olmutinib derivatives containing an acrylamide moiety (H1-H16) were synthesized and the pharmacological results indicate that most of the compounds exhibited moderate cytotoxic activity against five cell lines (A549, H1975, NCI-H460, LO2, and MCF-7). Among the most effective compounds, the $\mathrm{IC}_{50}$ values of $\mathbf{H 1 0}$ against A549 and $\mathrm{H} 1975$ cells were $3.36 \pm 1.59 \mu \mathrm{M}$ and $1.16 \pm 1.53 \mu \mathrm{M}$, respectively. The structureactivity relationship (SAR) indicated that the introduction of small-molecule swelling of dimethylamine was more favorable for the activity of the compounds. The amino group and morpholine rings formed hydrogen bonds on the 3ika and 3108 MET-793 residues, respectively. The kinase activity of compound $\mathbf{H 1 0}$ on PI3K was higher than that of the lead compound olmutinib at $1 \mu \mathrm{M}$, which indicates that compound $\mathbf{H 1 0}$ may be a new dual inhibitor of EGFR and PI3K. Further research will be conducted in the near future.

Supplementary Materials: The Supplementary materials are available online, Figures S1-S22: ${ }^{1} \mathrm{H}-$ NMR spectrum of compound H1-H16, 8, 9, 10a-10b, 11a-11b. Figures S23 and S24: ${ }^{13} \mathrm{C}-\mathrm{NMR}$ spectrum of compound H7 and H10. Figures S25-S50: TOF MS of compound H1-H16, 8, 9, 10a-10b, 11a-11b, 17a-17b, 18a-18b.

Author Contributions: W.Z., Q.P. and X.H. conceived and designed the experiments; X.H. and S.T. performed the experiments; F.Y. ran the bioassay evaluation and statistics analysis; and X.H., P.Z., S.X., W.Z. and Q.P. started the project and wrote the paper. All authors have read and agreed to the published version of the manuscript.

Funding: We gratefully acknowledge the generous support provided by The National Natural Science Funds (No. 21967009); Natural Science Foundation of Jiangxi, China (20202BABL216076); Science and Technology Project Founded by the Education Department of Jiangxi Province, China (GJJ190583) and Nanchang Key Laboratory of Molecular Targeted Anticancer Drug Design and Evaluation (2019-NCZDSY-007).

Institutional Review Board Statement: Not applicable.

Informed Consent Statement: Not applicable.

Conflicts of Interest: The authors declare no conflict of interest.

Sample Availability: Samples of the compounds H1-H16 are available from the authors.

\section{References}

1. Shepherd, F.A.; Rodrigues, P.J.; Ciuleanu, T.; Tan, E.H.; Hirsh, V.; Thongprasert, S.; Campos, D.; Maoleekoonpiroj, S.; Smylie, M.; Martins, R.; et al. Erlotinib in previously treated non-small-cell lung cancer. N. Engl. J. Med. 2005, 353, 123-132. [CrossRef] [PubMed]

2. Lynch, T.J.; Bell, D.W.; Sordella, R.; Gurubhagavatula, S.; Okimoto, R.S.; Brannigan, B.W.; Harris, P.L.; Haserlat, S.M.; Supko, J.G.; Haluska, F.G.; et al. Activating mutations in the epidermal growth factor receptor underlying responsiveness of non-small-cell lung cancer to gefitinib. N. Engl. J. Med. 2004, 350, 2129-2139. [CrossRef] [PubMed]

3. Kobayashi, S.; Boggon, T.J.; Dayaram, T.; Jänne, P.S.; Kocher, O.; Meyerson, M.; Johnson, B.E.; Eck, M.J.; Tenen, D.G.; Halmos, B. EGFR Mutation and Resistance of Non-Small-Cell Lung Cancer to Gefitinib. N. Engl. J. Med. 2005, 352, 786-792. [CrossRef]

4. Hiramatsu, M.; Ninomiya, H.; Inamura, K.; Okui, M.; Satoh, Y.; Fujiwara, M.; Yamori, T.; Kitagawa, T.; Ishikawa, Y. EGFR signal pathways selectively activated in lung adenocarcinoma. Cancer Res. 2007, 67, 5038.

5. Cohen, M.H.; Williams, G.A.; Sridhara, R.; Chen, G.; McGuinn, W.D., Jr.; Morse, D.; Abraham, S.; Rahmans, A.; Liang, C.; Lostritto, R.; et al. United States Food and Drug Administration Drug Approval Summary: Gefitinib (ZD1839; Iressa) Tablets. Clin. Cancer Res. 2004, 10, 1212-1218. [CrossRef] 
6. $\quad$ Engelman, J.A.; Zejnullahu, K.; Mitsudomi, T.; Song, Y.; Hyland, C.; Park, J.O.; Lindeman, N.; Gale, C.-M.; Zhao, X.; Christensen, J.; et al. MET Amplification Leads to Gefitinib Resistance in Lung Cancer by Activating ERBB3 Signaling. Science 2007, 316, 1039-1043. [CrossRef]

7. Janjigian, Y.Y.; Smit, E.F.; Groen, H.J.; Horn, L.; Gettinger, S.; Camidge, D.R.; Riely, G.J.; Wang, B.; Fu, Y.; Chand, V.K.; et al. Dual Inhibition of EGFR with Afatinib and Cetuximab in Kinase Inhibitor-Resistant EGFR-Mutant Lung Cancer with and without T790M Mutations. Cancer Discov. 2014, 4, 1036-1045. [CrossRef]

8. Kim, E.S. Olmutinib: First Global Approval. Drugs 2016, 76, 1153-1157. [CrossRef]

9. Chen, K.L.; Cho, Y.T.; Yang, C.W.; Sheen, Y.S.; Liang, C.W.; Lacouture, M.E.; Chu, C.Y. Olmutinib-induced palmoplantar keratoderma. Br. J. Dermatol. 2018, 178, 129-131. [CrossRef] [PubMed]

10. Kim, D.-W.; Lee, D.H.; Han, J.-Y.; Lee, J.; Cho, B.C.; Kang, J.H.; Lee, K.H.; Cho, E.K.; Kim, J.-S.; Min, Y.J.; et al. Safety, tolerability, and anti-tumor activity of olmutinib in non-small cell lung cancer with T790M mutation: A single arm, open label, phase $1 / 2$ trial. Lung Cancer 2019, 135, 66-72. [CrossRef] [PubMed]

11. Sakuma, Y.; Yamazaki, Y.; Nakamura, Y.; Yoshihara, M.; Matsukuma, S.; Nakayama, H.; Yokose, T.; Kameda, Y.; Koizume, S.; Miyagi, Y. WZ4002, a third-generation EGFR inhibitor, can overcome anoikis resistance in EGFR-mutant lung adenocarcinomas more efficiently than Src inhibitors. Lab. Investig. 2012, 92, 371-383. [CrossRef]

12. Dexin, K.T. ZSTK474 is an ATP-competitive inhibitor of class I phosphatidylinositol 3 kinase isoforms. Cancer Sci. 2007, $98,1638-1642$.

13. Namatame, N.; Tamaki, N.; Yoshizawa, Y.; Okamura, M.; Nishimura, Y.; Yamazaki, K.; Tanaka, M.; Nakamura, T.; Semba, K.; Yamori, T.; et al. Antitumor profile of the PI3K inhibitor ZSTK474 in human sarcoma cell lines. Oncotarget 2018, 9, 35141-35161. [CrossRef] [PubMed]

14. Folkes, A.J.; Ahmadi, K.; Alderton, W.K.; Alix, S.; Baker, S.J.; Box, G.; Chickowree, I.S.; Clarke, P.A.; Depledge, P.; Eccles, S.A.; et al. The identification of 2-(1H-indazol-4-yl)-6-(4-methanesulfonyl-piperazin-1-ylmethyl)-4-morpholin-4-yl-thieno[3,2-d]pyrimidine (GDC-0941) as a potent, selective, orally bioavailable inhibitor of class I PI3 kinase for the treatment of cancer. J. Med. Chem. 2008, 51, 5522-5532. [CrossRef] [PubMed]

15. Yao, E.; Zhou, W.; Lee-Hoeflich, S.T.; Truong, T.; Haverty, P.M.; Eastham-Anderson, J.; Lewin-Koh, N.; Gunter, B.; Belvin, M.; Murray, L.J.; et al. Suppression of HER2/HER3-Mediated Growth of Breast Cancer Cells with Combinations of GDC-0941 PI3K Inhibitor, Trastuzumab, and Pertuzumab. Clin. Cancer Rese. 2009, 15, 4147-4156. [CrossRef] [PubMed]

16. Shaw, R.; Cantley, L. Ras, PI3K and mTOR signalling controls tumour cell growth. Nature 2006, 441, 424-430. [CrossRef] [PubMed]

17. Verbitski, S.M.; Mullally, J.E.; Fitzpatrick, F.A.; Ireland, C.M. Punaglandins, chlorinated prostaglandins, function as potent Michael receptors to inhibit ubiquitin isopeptidase activity. J. Med. Chem. 2004, 47, 2062-2070. [CrossRef]

18. Zhang, B.; Zhang, Q.; Xiao, Z.; Sun, X.; Yang, Z.; Gu, Q.; Liu, Z.; Xie, T.; Jin, Q.; Zheng, P.; et al. Design, synthesis and biological evaluation of substituted 2-(thiophen-2-yl)-1,3,5-triazine derivatives as potential dual PI3K $\alpha / \mathrm{mTOR}$ inhibitors. Bioorg. Chem. 2020, 95, 103525. [CrossRef]

19. Lei, F.; Sun, C.; Xu, S.; Wang, Q.; Ouyang, Y.; Chen, C. Design, synthesis, biological evaluation and docking studies of novel 2-substituted-4-morpholino-7,8-dihydro-5H-thiopyrano[4,3-d]- pyrimidine derivatives as dual PI3K $\alpha / \mathrm{mTOR}$ inhibitors. Eur. J. Med. Chem. 2016, 116, 27-35. [CrossRef]

20. Zhao, B.; Lei, F.; Wang, C.; Zhang, B.; Yang, Z.; Li, W.; Zhu, W.; Xu, S. Design, Synthesis and Biological Evaluation of Novel Phenylsulfonylurea Derivatives as PI3K/mTOR Dual Inhibitors. Molecules 2018, 23, 1553. [CrossRef]

21. Wang, L.; Xu, S.; Liu, X.; Chen, X.; Xiong, H.; Hou, S. Discovery of thinopyrimidine-triazole conjugates as c-Met targeting and apoptosis inducing agents. Bioorg. Chem. 2018, 77, 370-380. [CrossRef] [PubMed] 